\title{
Letters from the top: a comparative control group study of CEO letters to stakeholders
}

\author{
Mark Fuller(i)
}

\begin{abstract}
This paper examines corporate social responsibility (CSR) reporting with a focus on communications from management. It examines letters from the board chair, CEO and/or senior CSR lead to gain a deeper understanding of how firms disclose their past performance and whether firms noted for the CSR reporting disclose their information in meaningfully different ways compared to other firms. Using a comparative analysis between treatment and control groups, we explore whether there is a difference in reporting approaches between a sample of highly regarded CSR reporters vis-à-vis firms recognized for their high profitability. Our findings suggest CSR-recognized firms discuss sustainability issues in greater quantity but without much meaningful difference in quality. We postulate a parabolic relationship between report quality and cost to explain this situation, discussing both the theoretical and the practical implications.
\end{abstract}

Keywords: Corporate social responsibility, CSR reporting, CEO communications, Voluntary reporting, Mandatory reporting, Stakeholder management, Letters to stakeholders, Canada

\section{Introduction}

CSR reporting activities have been explored in many contexts, with stakeholder theory playing a prominent role in both theory and practice (Waddock 2004; Reynolds and Yuthas 2008; Hahn and Lülfs 2014; Orzes et al. 2018). The relationships with various stakeholders, including community groups, customers, distributors, employee groups, investors, regulatory and government agencies, suppliers, as well as NGOs and third-party organizations, have also been well detailed (Barnard 1938; Pfeffer and Salancik 1978; Freeman 1984; Donaldson and Preston 1995; Wheeler and Sillanpää 1997; Laplume et al. 2008). Meanwhile, the integration of CSR reporting within the corporate annual reporting practices of the firm has also been examined (Sierra-García et al. 2015; IIRC 2017; Maniora 2017). Further, the firm's involvement with voluntary regulatory standards has been a source of investigation (Kolk et al. 1999; Logsdon and Wood 2005; Vogel 2008; Tuczek et al. 2018). An area that has been comparatively less addressed involves managerial discussion and analysis of past CSR performance and future CSR aspirations within the context of different stakeholder relationships.

Correspondence: mfuller@stfx.ca

Schwartz School of Business, St. Francis Xavier University, 3090 Martha Drive, Antigonish, NS B2G 2W5, Canada
Management's discussion and analysis of a firm's CSR activities are a critical component within a firm's reporting activities. It is the focal point of the reporting effort whereby management can discuss past CSR performance and explain variances from expectation, while also outlining future CSR objectives (Gray et al. 1987). This reporting activity is generally provided in a letter from management, nominally authored and signed by the chair, CEO or senior CSR manager. However, with CSR reporting remaining voluntary in most jurisdictions, not every firm produces an appropriate disclosure statement. When a CSR report is produced, it is not always on an annual basis, with a fixed reporting date, and with standard reporting components (Holder-Webb et al. 2009). Accordingly, some firms report biannually, others report irregularly, with statements from management varying widely in breadth and depth, and occasionally, are not included at all. Further, unlike the financial certification requirements that exist in some jurisdictions - whereby the CEO or CFO may be held liable in the event of false reporting (Gray 2005) and with research showing that certification requirements have impacts upon managerial disclosure (Garg 2018) - nonetheless, such certification requirements are absent in most jurisdictions for non-financial CSR 
disclosure. This makes insight into the firm's corporate social responsibility practices difficult to interpret in terms of past performance and anticipated future activities, particularly at the level of diverse stakeholder groups, which inhibits both chronological and cross-sectoral analysis. This article responds to this issue from a comparative qualitative analytical perspective. By adopting a cross-sectoral analysis with a comparator group, we strive to gain a deeper understanding of management thought, at a snapshot in time, across a variety of industries for a diversity of stakeholder groups. Therefore, the purpose of this article is to examine the content of these CEO letters to stakeholders by exploring the following research questions:

1. How does management report upon previous corporate social performance in their current CSR disclosures from the perspective of multiple stakeholders?

2. Does stakeholder-oriented reporting differ between firms recognized for their CSR activities and those firms that are highly profitable?

Following a review of the extant literature and a description of our research methods, our findings suggest firms privilege particular stakeholder groups - customers, communities, employees and regulators, respectively - over other stakeholders. Firms associated with highly-regarded CSR disclosures tend to reference stakeholders to a greater degree than firms associated with high degrees of financial sustainability, with additional differentiation at the level of individual stakeholders. Making sense of the differences in CSR reporting among firms necessitates an understanding of the relationship between the cost and the quality of enhanced CSR reporting. In our discussion of the implications for theory, we postulate that a parabolic relationship can best explain the gap between non-reporting and reporting firms, and the quality differences among firms engaged in CSR reporting. Our contribution to practice is a recognition that governmental promotion of the United $\mathrm{Na}$ tions' Principles for Responsible Management and the adoption of mandatory national CSR reporting regimes would make meaningful improvements to corporate disclosures in this regard.

\section{Literature review}

We performed a systematic chronological literature review of "corporate social responsibility reporting" in the business, management, and ethics literatures (Booth et al. 2016). We used this term as a key phrase (Hahn and Kühnen 2013) in order to focus upon a defined phenomenon, acknowledging that CSR reporting activities which preceded the use of this phrase previously existed but represented an ill-defined context within the CSR literature. Drawing upon the Web of Knowledge, Business Source Complete and Google Scholar, we traced the literature from the point of divergence in the 1970s within the corporate social accounting literature through to the present.

\section{The early years: $1971-1987$}

While Freeman (1984) attributed the emergence of the CSR literature to Sethi (1971), we found the earliest explicit reference to CSR reporting to van den Bergh's report on Deutsche Shell (Van den Bergh 1976). Soon after, Buzby and Falk (1979) examined expectations of university investors. They argued for the consideration of non-financial reporting as being of relevance to a plurality of stakeholders, moving beyond the concept of corporate social accounting identified earlier by Epstein et al. (1976). As Buzby and Falk $(1979,25)$ noted, "we believe ... that additional empirical research may be needed in order to ascertain the relative importance of different types of social responsibility data to various potential user groups" while offering that "the evidence is not sufficient to support a conclusion at this time that there is widespread interest in social responsibility reporting". Stakeholder perspectives were changing, however, culminating in Freeman's (1984) seminal work on stakeholder theory. His work highlighted the twin reporting dilemmas (Freeman 1984, 178): “(1) how do we measure our performance with each stakeholder and (2) how do we measure our performance with our entire set of stakeholders?" Freeman's composition explored issues of internal versus external validity in measuring near and long-term metrics of corporate social performance, drawing upon the previous work of both Post (1978) and Mendelow (1981), and remains relevant to our current exploration of CSR reporting. However, despite acknowledging a need to measure "performance as a whole" (Freeman 1984, 178), Freeman posits that "different measures may be appropriate for different customer segments and will depend on product, industry, etc." (Freeman 1984, 180). This inhibits the development of integrative CSR-related measures which Freeman acknowledges, while also constraining longitudinal and cross-sectional reporting analysis within an industry.

\section{Searching for a broader management context: 1987 to 1996}

The late 1980s-early 1990s generated quantitatively fewer articles on CSR reporting than has been witnessed more recently. We identified just 21 articles during this period that made explicit references to CSR reporting. Of the 21 articles, five originated from the field of organizational behavior and management studies, two from business ethics or philosophy, and the remainder 
from accounting and finance, reflecting a gradual emergence from the more financial aspects of corporate social accounting. Wood and Jones (1995) extended Wood's (1991a, 1991b) earlier work in the broader field of CSR to offer a framework for analysis, including features of stakeholder expectations setting, behavioral experiences, and performance evaluation. Others had attempted an integrative perspective as well: Freeman (1984) contributed to the epistemological and ontological lens through which corporate social responsibility could be considered from a stakeholder perspective, while Gray et al. (1987) added to the methodological considerations related to reporting activities. One such prescription highlighted the issue of information relevancy, and the lack of decision models for resolving this issue. They advocated for organizations to provide CSR objectives in order to contextualize the firm's information disclosure. One could argue that the growth in global reporting standards provides an implicit, if not explicit, set of reporting objectives. However, the outsourcing of an organization's CSR goals undermines a firm's implicit, intrinsic commitment to corporate social responsibility: if a firm is only providing disclosure according to external stakeholders using externally mandated measures, what higher order, intrinsic values does corporate social responsibility require from the firm?

\section{The quest for norms and the acceptance of variation: 1997 to 2010}

The search for broader managerial meaning begat a significant upturn in CSR research activity. Among the more notable contributions, Elkington (1998) offered unifying principles for crafting a meaningful CSR reporting regime. These include parallel communication between stakeholders and the firm with respect to reporting; independent verification of corporate reporting; comparability within and across firms; life cycle analysis of a firm's activities; input-output analysis; the globalization of reporting standards; the overarching umbrella of a corporate governance regime; the expected expansion of mandatory reporting; negotiated boundarysetting with stakeholders; and triple bottom line performance reporting. During this period, prescriptive studies strived to establish norms within the field of CSR reporting. Yet at the same time, research began to value differences in CSR reporting regimes. Attempts at contextualizing empirical research often were operationalized within the domain of geographic differences: legal and regulatory practices that varied by country having influenced reporting practices. Country-specific exemplars include Australia (Frost et al. 2005); Bangladesh (Imam 2000), Canada (Berthelot et al. 2012; Roca and Searcy 2012); Ireland (Douglas et al. 2004); Jordan (Naser 1999; Al-Khater and Naser 2003); Malaysia
(Thompson and Zakaria 2004); Qatar (Naser et al. 2006); South Africa (Dawkins and Ngunjiri 2008), Switzerland (Daub 2007), and the United States (Holder-Webb et al. 2009; Pled and Latridis 2012). In addition, there have been a number of valiant attempts at comparative studies (Adams et al. 1998; O'Rourke 2004; Chapple and Moon 2005; Kolk 2005; Perrini 2005; Matten and Moon 2008; Freeman and Hasnaoui 2011). At the same time, some advocates of stakeholder theory were rejecting normative approaches and embracing contingent approaches to strategic management (Kochan and Rubinstein 2000; Freeman and McVea 2001), which had direct implications for CSR strategy. In this vein, Holder-Webb et al. (2009) highlighted the differences in reporting frequency, disclosure methods and content emphasis among reporting firms. By embracing variation, a research schism began to evolve, which separated normative research grounded in the pursuit of platonic ideals of CSR practices, and those academics willing to embrace a diversity of CSR approaches and reporting methodologies.

\section{Consolidating CSR reporting: 2011 to present}

More recently, efforts have been undertaken to integrate research on CSR reporting. Hahn and Kühnen (2013) performed a much-warranted meta-review of 178 articles covering the period from 1999 to 2011. Their findings revealed researcher emphasis toward double bottom line reporting as the subject matter and document analysis as the dominant research method. Analysis of financial reporting was often omitted. This is likely due in large part to a minority of firms producing integrated annual reports, contrary to the findings of Daub (2007), which otherwise would enable standalone triple bottom line analysis; such analysis in a non-integrative reporting regime being possible only when annual reports and CSR reports are used collectively within a data sample (Fuller 2016). The authors found that the adoption rate for CSR reporting and the extent of that reporting were positively associated with various measures of firm size. Wang et al. (2016) performed a meta-analysis of 42 studies, finding a positive relationship of CSR as a driver of corporate financial performance.

\section{Mind the gap: searching for variation in stakeholder- specific disclosure practices}

Less well studied have been issues involving stakeholderspecific CSR reporting disclosures practices (Hahn and Lülfs 2014; Orzes et al. 2018), although the extant research has been increasing in recent years. While many studies reference stakeholder theory, including as a lens of analysis (Waddock 2004; Reynolds and Yuthas 2008; Barkemeyer and Figge 2014; Herremans et al. 2016), we 
find little empirical research which differentiates among multiple groups of stakeholders within CSR reporting disclosures (Orzes et al. 2018). Boesso et al. (2015) suggest prioritized CSR activities can lead to enhanced corporate social performance, particularly in relation to internal stakeholders. Meanwhile, Vazquez-Brust et al. (2010) distinguished environmental responses across 17 distinct stakeholder groups and found that stakeholder salience is not perfectly correlated with firm-level responses to environmental responses. Meanwhile, in differentiating interactive relationships among the firm and its stakeholders, Dobele et al. (2014) argue that the firm is a member of, but not central within, the network of stakeholder relationships in which it operates; that the interaction between the firm and its stakeholders are not dyadic in nature; and that interactive effects need to be assessed as part of complex stakeholder relationships. Without diverging into a discussion of network theory, which is beyond the scope of this article, we return to an examination of our central research questions involving stakeholder-specific CSR reporting and differences in the nature of that reporting for CSR-oriented firms.

\section{Research methods}

In exploring this topic, we sought to undertake a qualitative assessment of management's discussion and analysis within their CSR reports. Our focus comprised letters from management, nominally written by the chair, CEO or senior CSR executive. We next sought a dataset that would comprise an exemplar for CSR reporting and an appropriate comparator group. Our goal was to conduct an in-depth review of these letters, and compare these letters across industries, for a given reporting year.

\section{Data samples}

As Adams et al. 1998, 5) note specifically in relation to CSR research methods, "the choice of sample is dictated both by the specific objectives of the study and the more pragmatic consideration of data availability." Access to data in part explains the prevalence for the use of documentary analysis in the CSR field (Hahn and Kühnen 2013). In choosing exemplars of CSR reports, we sought a purposeful sample (Patton 2002) premised upon an independent third-party assessment of firms' reporting activities. We further sought to identify a CSR-oriented data set which emphasized report quality. We selected the Corporate Knights (2017) survey of the top 50 corporate citizens in Canada as their methodology is based upon 14 widely-reported metrics that span across industries, thereby fostering an opportunity for exploring the reporting practices of firms lauded for such activities. Other rankings were considered, but ultimately excluded due to being less timely, less transparent in terms of research methodology, or hidden behind paywalls which would impair external review of the data by our peers.

We then wished to compare our sample of CSR reporting exemplars with a sample of firms recognized primarily for their financial sustainability (Spreckley 1981; Elkington 1998), one of the hallmarks of triple bottom line management, rather than a random sample. The rationale for this second purposeful sample was that we did not wish to compare externally venerated CSR active firms to firms with unremarkable performance. Rather, we specifically sought to examine whether firms that are recognized for their CSR activities engage in disclosure activities that are markedly different than firms hailed for their financial performance. We considered a range of alternative comparisons for our control group, ultimately deciding upon the Report on Business (2017) ranking of the top 1000 most profitable firms in Canada due to the accessibility of the data for both authors and readers, as well as the transparency of the ranking methodology. As this was a preliminary study, we chose the top 10 firms on each list as representatives for our two sample sets. Where there was overlap - in the case of two firms, Royal Bank of Canada and Power Financial, parent of IGM Financial, both of which appeared on the Corporate Knights list - we chose the next highest-ranking firms on the Report on Business list. The results of our data sample therefore consisted of the following firms (Table 1):

\section{Data analysis}

We view CSR reports as a snapshot in time: they are an opportunity to commit the firm's activities to the annals of corporate history while engaging in thoughtful reflection upon recent achievements at the time of report publication. Whether the firm exercises the option or not, firms can reflect, interpret, and re-interpret past actions for the benefit of the present-day reader. It in unreasonable to expect stakeholders to have read previous CSR reports in order to contextualize management's present perspective. Words matter: precision in diction and consideration in presentation and structure impact stakeholder understanding, and the comparability of CSR reports both longitudinally and cross-sectionally. Care must therefore be taken in the words chosen and committed to the written page. Relatedly, management's letter to the reader of a CSR report may articulate future expectations about objectives, processes, and outcomes (Gray et al. 1987; Wood 1991a, 1991b) that the firm is pursuing within the realm of responsible management behavior. When management chooses to highlight ongoing activities, they elevate the importance of these activities over competing matters that they might otherwise have raised. Thus, in the context of addressing the research questions enumerated previously, we must 
Table 1 Sample Firms

\begin{tabular}{llll}
\hline Report on Business Data Set & Industry & Corporate Knights Data Set & Industry \\
\hline TD Bank & Financial services & Vancouver City Savings Credit Union & Financial services \\
Bank of Nova Scotia & Financial services & Mouvement des Caisses Desjardins & Financial services \\
Bank of Montreal & Financial services & HSBC Bank Canada & Financial services \\
CIBC & Financial services & Hydro-Québec & Utilities \\
CN Railway & Transportation & Cameco Corporation & Energy \\
Brookfield Asset Management & Property management & Enbridge Inc. & Energy \\
Great-West Life Co. & Insurance & Royal Bank of Canada & Financial services \\
Bell Canada Inc. & Telecommunications & IGM Financial Inc. & Financial services \\
Magna International & Automotive & The Co-Operators & Insurance \\
Manulife Financial & Insurance & Sun Life Financial & Insurance \\
\hline
\end{tabular}

be sensitive to how the firm presents past actions within the context of our present conceptions.

Prior to analysis, we acquired the CSR reports for each of the two data sets. This was not possible for one of the focal firms - Magna International - who did not have a sustainability report. For the remaining firms, we downloaded their most recent CSR reports - typically, but not always, 2016 publications. In the case of firms that produced multiple reports on a variety of responsible management-related topics, we privileged CSR reports over other forms of reporting, such as environmental, social, and governance reports and public accountability statements. From each report, we then extracted the letter from the CEO, Chair, or senior CSR thought leader for the firm. In some cases, CEOs and board chairs co-published a letter; in other cases, these

Table 2 Word Frequencies by Data Set

\begin{tabular}{|c|c|c|}
\hline Frequently Cited Words & Infrequently Cited Words & Notably Absent Words \\
\hline \multicolumn{3}{|c|}{ Report on Business Data Set } \\
\hline 2016 & Monitoring & Trade \\
\hline Corporate & Mitigation & Regulatory \\
\hline Customers & Millennials & System(s) \\
\hline Communities & Metrics & Policy \\
\hline Business & Measures & Reconciliation \\
\hline Employees & Marketplace & Reduction \\
\hline Responsibility & Loyalty & Target \\
\hline Executive & Learning & Process \\
\hline Social & Landfills & Reporting \\
\hline Governance & Inspiring & Results \\
\hline \multicolumn{3}{|c|}{ Corporate Knights Data Set } \\
\hline 2016 & Programs & Accountability \\
\hline Business & Initiative & Communications \\
\hline Sustainability & Responsive & Networks \\
\hline Communities & Prosperity & Workplace \\
\hline Clients & Participation & Trust \\
\hline Global & Liquidity & Advice \\
\hline 2017 & Ideas & Aspirations \\
\hline Energy & Diverse & Efficiency \\
\hline Change & Learn & Grassroots \\
\hline Management & Employment & Hope \\
\hline
\end{tabular}


were separate letters to stakeholders. In cases of multiple letters, all letters were included in the analysis, because when combined, they represent the most direct and holistic statements of the firm concerning their views on corporate social responsibility. In the case of integrated reporting, where the CSR report is integrated within the annual report - an emerging best practice (Sierra-García et al. 2015; IIRC 2017) - we included the letter to stakeholders.

To explore the research questions on past performance and comparative commentary, we developed a codebook prior to performing a thematic stakeholder analysis (Miles et al. 2014) on the top ten firms lauded by Corporate Knight magazine from their list of the top 50 Canadian reporters, as well as the ten most profitable firms from the Report on Business sample set, which served as our benchmark. To develop the codebook, we employed Nvivo qualitative analysis software to conduct a word frequency analysis of the two data sets. For each data set, we identified the 1000 most commonly employed words of three characters in length or longer. Table 2 synthesizes the notable words that are (a) frequently employed, (b) infrequently employed within the letters, (c) and notable words absent from one list but frequently present in the other list.

Consistent with our chosen analytical lens of stakeholder theory, we then examined each report for statements related to the following key entities: customers, employees, investors, suppliers, distributors, regulators and government, community organizations, and non-governmental organizations (explicitly by name and implicitly by reference). We also explored issues of time, both past and present, as relevant to our specified research questions. Treating each CSR letter to stakeholders as a single case, we performed within-case, cross-case and pairwise analysis (Eisenhardt 1989; Miles and Huberman 1994) for the 19 CSR documents. This enabled us to identify similarities and differences in the temporal context (past performance versus future intent), the sectoral context (through a cross-sectional analysis), and the social responsibility context (responsible management versus profit dominant). We supplemented this with word frequency analysis as part of our thematic analysis, to better understand the nature of the communiques from each organization.

\section{Findings}

\section{Reporting upon previous corporate social performance}

Our first research question inquired as to how management synthesizes previous corporate social performance in their current CSR reporting disclosures. We examined the issue from the perspective of community groups, customers, distributors, employees, investors, non-governmental organizations, regulatory and government agencies, and suppliers. Customers and clients were the most frequently discussed stakeholder group, followed closely by community groups. Customers were often discussed in the context of the benefits that new products or services would provide them; how changing consumer trends (buying habits, use of technology, etc.) were impacting the firm or the industry; how the firm was seeking to shape consumer practices; and the nature of improvements to the customer service experience. Reporting firms, on occasion, would link customer relations actions to the firm's operations or to issues of a broader concern. For example, Manulife $(2017,2)$ stated "we believe our greatest contribution to society is the products and services we provide, which offer customers peace of mind, financial security and help when they need it most." thus documenting the interrelationship between the firm's operations and the value proposition specific to a particular stakeholder group.

Community groups were the second most frequently referenced stakeholder group in the letters from the CEOs. Within the context of past performance, this relationship is frequently characterized by descriptions of investments in general, or to promote a range of interests via targeted investments. Engaging and consulting with stakeholders; providing a source of employment to targeted communities, and relatedly, being representatives of the communities with which the firm is involved; and achieving a positive impact or a mutually-beneficial relationship, are common characterizations. The values of the organization are often illustrated anecdotally in the narratives shared within the CEO letters, and throughout CSR reports more generally. Relationships with community stakeholders were also used as a point of differentiation between the firm and its competitors. As Vancity $(2017,2)$ stated "credit unions like [ours] have the ability to identify community needs and address them in much more creative ways than traditional financial institutions," reflecting perceptions of differing stakeholder relationships between the two types of financial institutions.

Employees were the third most referenced stakeholder group, mentioned less than half as frequently as customers and community groups. Firms associated employees with both achieving organizational goals (Caisse DesJardins) and the attraction and retention of employees because of organizational goal achievement (Cameco). As the latter firm noted (Cameco 2016, 3), "our people have found ways to be innovative, to do more with less, and to continue to keep this company competitive. And, they've done that without compromising on our commitments to safety, the environment, or our communities," thus connecting the activities of one stakeholder group to the interests and welfare of other stakeholders. The commitment of employees was associated with benefitting society broadly 
(Hydro-Québec) and having a social impact (RBC). An inclusive corporate culture, coupled with a high degree of employee engagement, was viewed as enabling employee productivity (Sunlife). Workplace safety also played a recurring role for many firms (Brookfield Asset Management, CN Rail, Enbridge).

Next most mentioned were regulatory agencies and government, which we have combined in our analysis, as one is frequently an extension of the other. Of all 19 reporters reviewed, five commented on governance and/or regulatory matters: Bank of Montreal, Enbridge, HSBC, Royal Bank, and Vancity. Twenty-seven regulatory or governmental references were identified across the four firms, with 23 originating from HSBC which dedicated a whole section to the topic. Issues included HSBC's 'disappointment' over the inability of the regulatory community to achieve consensus on change and the UK vote on Brexit. HSBC $(2016,5)$ also used their CSR report as a medium for advocacy in relation to the future regulatory environment, by stating "the best outcome would be early global agreement on unresolved issues, followed by an extended period of regulatory stability to allow familiarity and experience to be gained from what has been put in place." Other stakeholder groups received comparatively less coverage in letters from management. These include investors (18 references), distributors (9 references), non-governmental organizations (2 references) and suppliers (1 reference).

What is absent from CEOs' letters is measurable specificity in how their relationships with key stakeholders have achieved objectives related to improved corporate triple bottom line performance (Gray et al. 1987; Hahn and Kühnen 2013). Caisse DesJardins reported increased financial sustainability, as did Vancity in terms of both their assets and their assets under management. Meanwhile, HSBC reported on a share repurchase, which had a financial benefit to investors. However, most statements on performance changes were vague and ambiguous. For example, Caisse DesJardins $(2016,6)$ reported "an increase in membership, which gives us confidence in the future" while Enbridge $(2017,6)$ asserted that they "continued to develop long term plans for increasing their energy efficiency and decreasing their direct and indirect GHG emissions" with insufficient elaboration as to either timelines or targets. HSBC reports progress "in reshaping the Group to improve productivity, embrace technological change and reinforce global standards of business conduct". However, some firms are aware of the vagaries typically present in CSR reporting, and have acknowledged the need for improvement. Sunlife $(2016,5)$ for example, stated

we recognize the need to advance our reporting to meet evolving stakeholder expectations. That's why we have made a number of improvements to this year's report, including providing more meaningful, consistent performance data. We know we have more work and refinement to do, particularly around establishing our benchmarks and targets, all of which will help us to better measure and evaluate our progress on our priority topics.

\section{Comparative reporting of CSR activities}

We next turn our attention to the second research question: how do stakeholder reporting by firms acknowledged for CSR activities differ from those of highly profitable firms? For eight stakeholder groups, we coded their use in the management letters from the reporters. Of the 291 coded references, 176 references were attributed to Corporate Knights-listed firms, and 115 to the Report on Business firms, which served as our control group. With the exception of the employee stakeholder group, the other seven stakeholder groups all were referenced to a greater degree by CSR-oriented firms. The results are summarized below (Table 3):

Evidentiary findings demonstrate a greater frequency of discourse for most stakeholder relationships among CSR-oriented firms. Yet is this greater frequency of discussion meaningfully different from a qualitative perspective? When it comes to customers as stakeholders, Sunlife describes their commitment with greater specificity than many Report on Business-ranked firms. Their future-oriented goals include enhancing the customer experience to reduce the complexity of the business relationship; increasing the frequency of client communication; and improved problem resolution of client issues. A greater degree of goal specificity was found in the writings from HSBC who are "seeking to influence client practices and to build the data, the tools and the transparency necessary to embed understanding of climate risk into the way that markets function." (HSBC 2016, 9), combined with enhanced environmental scanning and process innovation. In contrast, Bell Canada, a firm from the Report on Business data set with the most extensive referencing related to customers, chose to highlight their current operational activities. Their future-oriented strategic imperatives were vague and uninspired. Conversely, the four firms with the fewest customer-oriented codings were drawn equally from both data sets, and had tangential discussions of customers as stakeholders.

There was some differential evidence in the reporting about community groups between firms from the two data sets. Vancity, the Corporate Knights-ranked firm with the most codings pertinent to community groups, highlighted their ability as a credit union to better identify community needs in comparison to banking and 
Table 3 Stakeholder References by Data Set

\begin{tabular}{|c|c|c|c|c|c|}
\hline Stakeholder & $\begin{array}{l}\text { Report on Business } \\
\text { Data Set }\end{array}$ & $\begin{array}{l}\text { Mean No. Citations per } \\
\text { Report }\end{array}$ & $\begin{array}{l}\text { Corporate Knights } \\
\text { Data Set }\end{array}$ & $\begin{array}{l}\text { Mean No. Citations per } \\
\text { Report }\end{array}$ & $\begin{array}{l}\text { Total } \\
\text { References }\end{array}$ \\
\hline Customers & 45 & 5.00 & 56 & 5.70 & 101 \\
\hline Community Groups & 41 & 4.56 & 53 & 5.30 & 94 \\
\hline Employees & 22 & 2.44 & 17 & 1.70 & 39 \\
\hline Regulators and Government & 0 & 0.00 & 26 & 2.60 & 26 \\
\hline Investors & 4 & 0.44 & 14 & 1.40 & 18 \\
\hline Distributors & 1 & 0.11 & 8 & 0.80 & 9 \\
\hline $\begin{array}{l}\text { Non-Governmental } \\
\text { Organizations }\end{array}$ & 1 & 0.11 & 1 & 1.00 & 2 \\
\hline Suppliers & 1 & 0.11 & 0 & 0.00 & 1 \\
\hline Total References & 115 & 12.78 & 176 & 17.60 & 291 \\
\hline
\end{tabular}

other financial institutions. This is interesting for a number of reasons. First, four of the major banks in Canada are on the Report on Business data set (the fifth of the five banks, RBC, was on both the Corporate Knights and Report on Business lists, but for the purposes of classification, was included on the Corporate Knights data set). Second, there are non-bank financial services firms (i.e. insurance companies, financial planning services) on both the control group Report on Business data set and the Corporate Knights data set, suggesting that it is not the industry that defines upon which list the firm falls, but the actions of management, in particular, their handling and reporting of corporate social responsibility activities. Meanwhile, the Co-Operators Insurance company expressed in writing their perception of the interconnectedness between their members, clients and communities, rather than viewing each stakeholder as being in a dyadic relationship with the firm (Dobele et al. 2014). Cameco's letter explained why the commitments that the firm makes to community groups - and others - is noteworthy: "the importance of these commitments cannot be overstated. They are not add-ons, or 'nice-to-haves'; they make up the very foundation for how we do business. They help us build trust and credibility, gain and protect community support for our operations, attract and retain employees, and manage risk" (Cameco 2016, 3). In so doing, the firm both extends the discussion and contextualizes the nature of the relationship, attributes that were lacking in many rivals' letters to stakeholders, particularly when compared to Report on Business-ranked firms. Some firms also reported on the need to improve their CSR disclosure practices. The senior managing director for Sunlife stated in his letter ( 2016, 6):

As we continue along this journey, our stakeholders can expect to see us do more to ensure our sustainability ambitions are holistic and outcomebased. While our activities may vary from country to country, they are centered around a common theme: building sustainable, healthier communities for life.

The 'meaningful, consistent performance data' of which Sunlife's CEO spoke earlier is a characteristic absent in many CSR reports from both data sets. As Sunlife's senior managing director notes, this requires having inclusive and outcome-centric CSR objectives as the initial point of departure in the reporting process. Contributing to this issue is the remarkable lack of depth in the CSR reporting by firms from the Report on Business data set.

Other than the employees as stakeholders topic, where Report on Business-ranked firms referenced the topic more frequently than Corporate Knights-ranked firms (22 references to 17 references), most other stakeholder groups were addressed far more comprehensively by firms lauded in the Corporate Knights magazine. This holds particularly true for regulators (26 references by Corporate Knights-ranked firms; 0 references by Report on Business-ranked firms), investors (14 to 4), and distributors $(8$ to 1$)$. The exceptions were non-governmental organizations (one reference each) and suppliers (1 reference only, by ScotiaBank, a firm from the Report on Business data set). CSR-oriented firms spoke of their role in, and the benefits associated with, clear and consistent regulatory policy frameworks; the intermediary role of the firm between investors and other stakeholders; and the role of new distribution models in reaching under-serviced segments of society. In reviewing CSR reporting on past performance and future expectations, and comparing CSR-oriented firms ranked by Corporate Knights to a control group of Report on Business-ranked firms recognized for their profit orientation, we have described a general but not universal pattern whereby firms that are CSR-oriented report in greater detail about the nature and extent of the relationships with stakeholders. Yet we also acknowledge a lack of meaningful difference between our test and 
control groups in terms of their analytical depth, representing a gap in describing pre-established organizational goals in the context of desired targets and current levels of performance. The extent to which firms that have been recognized for their CSR reporting contributions actually leverage their CSR activities for strategic benefit is left undetermined, with the future for enhanced CSR reporting uncertain. Such a finding has implications for both future research and current organizational practice.

\section{Discussion}

Our paper sought to address two key questions: how do firms describe past corporate socially responsible behavior in the context of different stakeholders, and whether this reporting varies between firms recognized for different forms of business success. With our control group consisting of firms associated with high levels of profitability, we compared them to firms whose CSR reporting have received accolades, using the most salient indicator of management thought - letters to stakeholders. Our analysis indicated a varying degree to which each stakeholder group was addressed within the CSR reports, and in particular, a general but not universal trend toward expanded stakeholder discussion. However, while stakeholder discourse was somewhat more extensive among the firms recognized for their CSR disclosure practices, we did not ascertain a meaningful difference in the quality of the communications. From a strategic perspective, firms of both stripes frequently avoided stating CSR objectives in measurable terms, lacked consistent information disclosure, abstained from the specification of performance targets, and engaged in a minimum of reflective analysis as to the underlying causes and future responses to their present performance results. As has been noted previously (Gray et al. 1987; Wood 1991a, 1991b; Wood and Jones 1995), this remains a persistent problem within our field; the current state of CSR reporting, even among firms noted for their CSR disclosure, left us troubled.

We can postulate as to a theoretical explanation which might explain the substantive lack of advancement in CSR reporting quality for CSR-recognized firms compared to profit-oriented firms. In discussing Implications for Theory which follows, we hypothesize as to the existence of a parabolic relationship between the cost of CSR reporting and the quality of CSR disclosure. The postulated curvilinear relationship will be shown to address many of the complexities involved, including moving firms from being non-participants to participants in CSR disclosure; explaining the increased breadth of CSR disclosure while disclosure quality remains mired in anecdotal evidence; and the reluctance by firms to embrace high quality disclosure, which we associate with the setting of strategic CSR objectives, the establishment of measurable targets, and the analysis of performance variances.

In discussing Implications for Practice, we suggest the incentivization of firms to adopt voluntary disclosure in accordance with the United Nations Global Compact (UNPRME 2017), followed eventually with mandatory national CSR reporting standards subject to a phased implementation over a number of years, drawn from experience in other jurisdictions. It is our contention that such a policy framework will first motivate and then compel firms to initiate and expand their CSR disclosure activities, resulting in an improvement in the breadth and depth of disclosure. With mandatory reporting regimes present in an expanding number of jurisdictions, including Australia (Frost et al. 2005), China and Malaysia (Ioannou and Serafeim 2017), South Africa (Ackers et al. 2015), a number of ASEAN member states (CSR Asia 2016), and the EU member states (Knopf et al. 2011; Kühn et al. 2014), the global drumbeat encouraging enhanced CSR disclosure and reporting policies grows louder.

\section{Implications for theory}

A critical factor which may address the gap between strategic benefits derived from CSR investments, and the quality of CSR reporting, may be captured in the costs associated with expanding data acquisition and analysis. In examining the relationship between the cost and the quality of enhanced CSR reporting, we can hypothesize as to the nature of the relationship. One possibility is that the relationship is positive and linear, as this would imply that an increase in CSR reporting expenditure is associated with a positive impact on CSR reporting quality. Such a relationship is unlikely, however, as it would incentivize voluntary reporting of ever-improving quality which has not been widely witnessed, as many firms have resisted producing a CSR report to date, along with the widespread absence of CSR objectives, which are measurable, consistently reported, and outcome-based (Gray et al. 1987; Wood 1991a; Elkington 1998); the latter being a condition acknowledged by Sunlife's (2016) senior management. Further, it fails to explain the reticence of some firms to adopt any form of reporting when such reporting is voluntary (Logsdon and Wood 2005; Tuczek et al. 2018). Another possibility is that the relationship is horizontally linear, although this, too, is unlikely as firms would have neither benefit nor disincentive to report; evidence shows, however, that some firms choose to report voluntarily, even when there is a cost to do so (Chen and Bouvain, 2008; Hahn and Kühnen 2013). Further, the relationship is unlikely to be downward and linear, as this would represent a disincentive to report as costs escalate while reporting quality perpetually declines. And yet, 
rising reporting costs while reporting quality declines may be associated with the costs of expanded CSR reporting quantity - such as the collection, editing and production costs associated with the myriad of anecdotal stories replicated within CSR reports today. More likely is a non-linear relationship between the costs of CSR reporting and the quality of the reporting that is produced.

We posit that a curvilinear, U-shaped quadratic relationship exists between the cost of CSR reporting and the quality of CSR reporting. This relationship would suggest an initial benefit for low-level reporting, a disincentive for mid-quality reporting, and an

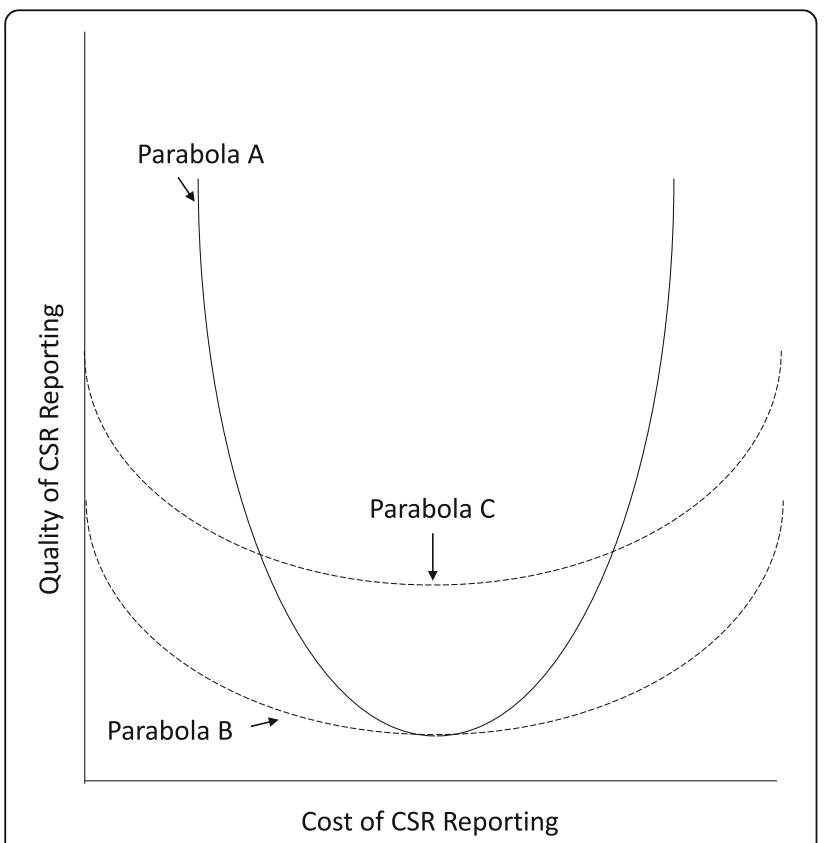

Fig. 1 Three Relationships Between the Cost of CSR Reporting and the Quality of CSR Reporting. Figure 1 illustrates three prospective relationships between the cost associated with the CSR reporting activity and the quality of CSR reporting. All three relationships are conceived as parabolic in nature, intended to illustrate an initial decline in the depth of reporting as the cost of CSR reporting increases. These added costs are associated with an increase in the quantity of narrative matter - stories, illustrations, stakeholder profiles, etc. These narratives may be informative, but their unstructured nature inhibits comparative performance assessments within the firm over time, and in relation to rivals. Parabola A

illustrates a gap between the $Y$-axis and the $Y$ asymptote, illustrative of a barrier to initiating CSR reporting. Parabola $A$ also features a gap between the vertex and the $X$-axis, which represents the minimum reporting quality level. Parabola $B$ is a dilation of the original parabola, reflecting a reduction of the barriers of entry to CSR reporting. This would be illustrative of a mandatory reporting regime, where firms are legislatively compelled to produce a CSR report. Parabola $\mathrm{C}$ is associated with both mandatory reporting and a higher quality level of reporting, as would be expected from the implementation of specific reporting methods, similar to what is required in the disclosure of a firm's annual report. This is represented by an upward vertical translation of Parabola B eventual benefit from high quality reporting (Wood 1991a, Gray et al., 1987), associated with an increased cost of attainment. This relationship is represented as Parabola A in Fig. 1 below.

If the relationship between the hypothesized cost and quality of CSR reporting is true, as reflected in Parabola A, it would explain a great many things. First, that while there is a cost involved in transitioning from being a non-reporter into a CSR reporter (Perrini 2005; Daub 2007; Chen and Bouvain, 2008; Hahn and Kühnen 2013; Fernandez-Feijoo et al. 2014), that the benefits for some firms outweigh the costs for firms that are able to move beyond the vertex to the right side of the parabola. It further explains why the cost of CSR reporting may increase without an improvement, indeed with a decline, in the quality of CSR reporting. If the quality of CSR reporting is defined as the provision of measurable, consistently tracked, and regularly disseminated outcome-based performance data (Gray et al. 1987; Wood 1991b; Wood and Jones 1995; Elkington 1998), then CSR reports which expand to include the greater use of narrative, including more anecdotal examples and colorful illustrations, would be associated with both a higher cost of production and a simultaneous decline in reporting quality. Further, it offers a rationale as to why firms have not adopted more quantitative, analytical assessments of their CSR practices and performance that has been raised previously (Gray et al., 1987; Elkington 1998): because the incremental benefit of enhanced quantitative disclosure (as represented by the right half of the parabola) is presently offset by the incremental cost that coincides with firms expanding upon their CSR narratives.

Variations on the nature of the curvilinear relationship raise some interesting theoretical issues. If we dilate the parabola by reducing the co-efficient alpha $(|a|<1)$, then Parabola A will be stretched to become closer to Parabola B. With the vertex remaining unchanged, a smaller $a$ will move the left arc of the parabola closer to the vertical axis (assuming $x>0$ for all points on the parabola). This has the effect of reducing the cost of entry for firms wishing to initiate CSR reporting activities, and would also be associated with the implementation of a mandatory reporting regime where CSR disclosure is required by law. This would help overcome the large-sized firm advantage (Chen and Bouvain, 2008; Hahn and Kühnen 2013) which presently impedes smaller firms from benefitting from gains associated with CSR reporting. Conversely, it draws out the cost of implementation, resulting in a greater cost for implementing higher quality CSR reporting as represented by movement along the $\mathrm{x}$-axis toward the right side of the parabola, which may prolong the inconsistency in CSR reporting quality 
(Holder-Webb et al. 2009). Another possibility is that we translate the parabola. By translating it vertically, we achieve higher quality CSR reporting at all points, irrespective of the costs at each level of reporting.

An improved result for the firm may be achieved by combining both a dilation and a translation of Parabola A. This is illustrated in Parabola $C$ which has some beneficial properties. First, when the parabola is closer to the Y-intercept, the firm more readily achieves the initial benefit of voluntary CSR reporting while minimizing cost outlays. Second, that for the left side of the parabola, the quality of CSR reporting declines less rapidly with increases in cost. However, a negative effect is that for firms able to breakthrough to high quality reporting - as represented by movement beyond the vertex to the right side of the parabola - such action results in much higher costs of implementation than in Parabola A. Ideally, the firm might achieve a split quadratic relationship, combining the left side qualities of Parabola $\mathrm{C}$ for the initial foray into CSR reporting with the high return benefits found on the right side of Parabola A as they improve the quality of their CSR reporting. Achieving such a curvilinear relationship would require some practical changes in regulatory policy as it pertains to CSR reporting, as noted in the section which follows.

\section{Implications for practice}

Moving from theory to practice, how might we improve the CSR reporting adoption rate by non-reporters, and increase the quality of high end reporting for existing reporters, while minimizing the costs of implementation? If a dilation or translation of our hypothesis that a parabolic relationship exists between the cost and quality of CSR reporting is true, then reducing the gap between the $y$-axis and the $y$-asymptote is necessary to facilitate firms undertaking CSR reporting for the very first time. This implies a reduction in the initial cost outlays associated with CSR reporting. These start-up costs can be associated with the recruitment and selection of CSR specialists; the development of a CSR strategy and the associated information disclosure plan; data acquisition costs; data analytics; and report writing and dissemination expenses. Two regulatory changes that could facilitate the wider adoption of CSR practices are governmental promotion of United Nations-sanctioned responsible management strategies (UNPRME 2017), followed eventually by legislatively mandated reporting of CSR activities.

Corporate social responsibility is a subset of responsible management practices. As Laasch and Conway (2015) describe them, responsible management includes championing stakeholder responsibility, triple bottomline management, and moral excellence within the firm. A government-led, industry-supported effort promoting the adoption of responsible management practices would be a beneficial first step at increasing the number of early adopters to practices which subsume CSR principles, policies and practices. When followed with the subsequent adoption of a previously announced mandatory CSR reporting legislation, firms will have an incentive to voluntarily undertake responsible management programs, or be eventually compelled to disclose CSR activities while facing a competitive disadvantage (Knopf et al. 2011; Kühn et al. 2014; Ackers et al. 2015). The two policy initiatives would result in firms moving along the left side of the parabola by participating - whether voluntarily or through mandatory disclosure - in CSR-related business activities.

A greater challenge is moving firms along the parabola. Traversing the vortex necessitates a willingness to endure the sunk costs associated with reaching the vortex; the additional costs as the firm moves to the right of the axis of symmetry; and a willingness to change the nature of their CSR reporting activities from anecdotal evidence toward strategic CSR planning, implementation, disclosure and refinement. This requires methods to incentivize firms to improve reporting quality while incurring additional expenses. Early CSR adopters can be expected to push forward with their enlightened agendas, as their equilibrium reporting states reached in the first phase - the encouragement of responsible management practice followed by mandatory CSR reporting - no longer provide sufficient differentiation to achieve a competitive advantage. Mandatory CSR reporting for incorporated firms will in particular serve as an effective driver of improved reporting participation. Even ill-defined reporting standards have been found to lead to improvements in disclosure frequency and quality, such as when the Canadian government required mandatory public accountability statements for the country's largest banks (Downing 2003; Fuller 2010). When mandatory reporting standards are subsequently revised for greater specificity, and extended to promote greater breadth of content coverage, differentiation\#seeking firms will pursue further opportunities to address the underserviced needs of enlightened stakeholders through, in part, higher quality CSR disclosure.

\section{Limitations}

In discussing management's treatment of stakeholders via CSR disclosure, we wish to acknowledge some limitations to our study. An initial constraint involves the availability of data. Given that CSR disclosure is voluntary in most jurisdictions (Logsdon and Wood 2005; Tuczek et al. 2018), not all firms produce CSR reports. Indeed, in a companion study to this report, we undertook a random sample of 3000 Canadian corporations from a pool of more than 12,000 incorporated firms and were able to identify just 40 Canadian firms that 
produced a CSR report in the 2016 reporting year irrespective of business size, a disclosure rate of just 1.33\%. This reinforces previous findings that CSR reporting is primarily associated with large firms (Perrini 2005; Daub 2007; Chen and Bouvain, 2008; Hahn and Kühnen 2013; Fernandez-Feijoo et al. 2014). While the size of the data sample is sufficient for the qualitative analysis we undertook, a larger comparative data sample has the potential to yield further results of interest.

A second limitation involves the volume of data in the data sample. Our focus upon letters to stakeholders intentionally excluded much content in each CSR report. This was necessary to focus upon management's discussion and analysis of the firm's performance, separate from the narrative content that varies widely in quantity and quality among CSR reporters (Holder-Webb et al. 2009). This decision, however, constrained the amount of material for which we could undertake our corporate discourse analysis. This is also a reflection of the limitations of management discussion and analysis presented within CSR reports as compared to the more voluminous annual reports (Fuller 2016) of the same firms. As the practice of CSR disclosure evolves, it is our hope that the extent of CSR-related MD\&A increases correspondingly.

A third constraint involves the use of disaggregated CSR reporting. Our study employed CSR reports to maximize the comparability of disclosure for the purposes of analysis. However, firms may disaggregate their CSR reporting efforts across additional platforms, including environmental, social and governance reports, diversity and inclusion reports, public accountability statements, media releases, websites, and social media platforms. (Holder-Webb et al. 2009; Hahn and Kühnen 2013; Dobele et al. 2014). While the use of disaggregated reporting may enable greater relevancy for specific stakeholder groups, such fragmented reporting serves as a systemic impediment to researchers within this field. This is a condition unlikely to be remedied except through greater adoption of widespread voluntary codes of conduct (e.g., the Global Reporting Initiative) or via mandatory reporting and governmental regulation of disclosure practices, as recommended above.

A further constraint relates to our methods of data analysis. We undertook a discourse analysis of corporate documentary evidence. This approach is consistent with the dominant research methods employed in CSR reporting research and included triple bottom line research, where possible, which is atypical in this field of study due to limitations with the availability of the data (Hahn and Kühnen 2013). While this approach was necessary - given that our purpose involves how firms express their CSR activities through their letters to stakeholders - a more holistic approach to the topic may have involved interviews with managers and/or external public relations firms involved in the creation of the disclosure documents with a view to developing case studies of the focal firms (Miles and Huberman 1994; Miles et al. 2014). This approach could have also expanded the variety of data sources employed, as noted previously, and in so doing, enabled the triangulation of information from across multiple sources (Eisenhardt 1989) in order to produce a longitudinal analysis.

\section{Future research directions}

Within the expanding field of corporate social responsibility research, there remain many promising avenues for additional scientific exploration. Building upon the knowledge gap and the contributions of this paper, we wish to highlight two interrelated directions that warrant further study. The more practical, bounded direction is the use of experimental research designs to simulate the future evolution of CSR reporting. Hahn and Kühnen $(2013,9)$ noted that document analysis accounts for $58 \%$ of empirical research in CSR studies, with experimental designs accounting for less than $1 \%$ by comparison. Understanding whether a parabolic (or other) relationship serves as a barrier to entry has intrinsic importance, but also as a vehicle for improving our understanding of CSR reporting adoption rates. This area of research is not well served by inferential statistical analysis nor by qualitative research to date. Multiple hypothetical relationships, particularly ones that can be tested as they evolve over time, lend themselves well to iterative empirical research designs.

The less bounded research opportunity involves advancing a truly triple bottom line business environment (Elkington 1998) through participatory action research, which is a novel approach to the study of empirical CSR research (Hahn and Kühnen 2013). This would require a combination of securities regulation and/or governmental legislation in order to reach a critical mass of firms, as faculty outreach to encourage firms to adopt CSR reporting processes would likely have a marginal impact on the overall percentage of voluntary CSR reporters. Cultivating social capital to influence securities regulators to adopt mandatory CSR disclosures for publicly-traded firms has the potential to impact all publicly-traded firms in Canada as it has in the European Union (Knopf et al. 2011; Kühn et al. 2014) and South Africa (Ackers et al. 2015). The use of information provisioning, via the distribution of academic research and practitioner articles encouraging greater firm-level CSR disclosure, and the use of grassroots campaigning (Wu and Choi 2004) are two social capital methods that may advance this intellectual agenda. Unfortunately, co-opting securities regulators excludes privately held firms, unincorporated businesses, and foreign-listed firms from coverage under the regulatory jurisdictional umbrella. The use of political lobbying, 
testifying before government committees, and the cultivation of relationships with political elites are some of the means through which legislative reform could be achieved (Baysinger 1984; Hillman and Hitt 1999; Keim 2001; Hillman 2005). Only through the governmental adoption of mandatory CSR reporting regimes are a significant number of non-reporting firms likely to adopt CSR disclosure practices, and participatory action research holds the promise for significant advancements in this emergent field of research.

\section{Abbreviations \\ CEO: Chief executive officer; CFO: Chief financial officer; CSR: Corporate social responsibility; IIRC: International Integrated Reporting Council; \\ MD\&A: Management's discussion and analysis; NGO: Non-governmental organization; RBC: Royal Bank of Canada; UNPRME: United Nations Principles for Responsible Management Education}

\section{Availability of data and materials}

CSR reports are publicly available from the individual firms.

\section{Authors' contributions}

This paper in a sole authored contribution. The author read and approved the final manuscript.

\section{Consent for publication}

This is an original work that has not been published, nor submitted for publication elsewhere.

\section{Competing interests}

The author declares that he has no competing interests.

\section{Publisher's Note}

Springer Nature remains neutral with regard to jurisdictional claims in published maps and institutional affiliations.

Received: 5 January 2018 Accepted: 1 August 2018

Published online: 03 September 2018

\section{References}

Ackers, B., Eccles, N. S., \& Parker, L. (2015). Mandatory corporate social responsibility assurance practices: the case of king III in South Africa. Accounting, Auditing \& Accountability Journal, 28(4), 1.

Adams, C. A., Hill, W. Y., \& Roberts, C. B. (1998). Corporate social reporting practices in Western Europe: legitimating corporate behaviour? The British Accounting Review, 30(1), 1-21.

Al-Khater, K., \& Naser, K. (2003). Users' perceptions of corporate social responsibility and accountability: evidence from an emerging economy. Managerial Auditing Journal, 18(6/7), 538-548.

Barkemeyer, R., \& Figge, F. (2014). CSR in multiple environments: The impact of headquartering. Critical Perspectives on International Business, 10(3), 124-151.

Barnard, C. I. (1938). The functions of the executive. Cambridge, MA: Harvard University Press.

Baysinger, B. D. (1984). Domain maintenance as an objective of business political activity: an expanded typology. Academy of Management Review, 9(2), 248-258.

Berthelot, S., Coulmont, M., \& Serret, V. (2012). Do investors value sustainability reports? A Canadian study. Corporate Social Responsibility \& Environmental Management, 19(6), 355-363. https://doi.org/10.1002/csr.285.

Boesso, G., Favotto, F., \& Michelon, G. (2015). Stakeholder prioritization, strategic corporate social responsibility and company performance: further evidence. Corporate Social Responsibility \& Environmental Management, 22(6), 424-440.

Booth, A., Sutton, A., \& Papaioannou, D. (2016). Systematic approaches to a successful literature review. Thousand Oaks: Sage.

Buzby, S. L., \& Falk, H. (1979). Demand for social responsibility information by university investors. Accounting Review, 54(1),23-37.

Cameco. (2016). On track. Cameco https://www.cameco.com/sustainable_ development/2016/. Accessed 10 June 2017.
Chapple, W., \& Moon, J. (2005). Corporate social responsibility (CSR) in Asia: a seven-country study of CSR web site reporting. Business \& Society, 44(4), 415-441.

Chen, S., \& Bouvain, P. (2008). A Comparison of Corporate Social Responsibility Reporting in the United States, Germany and Australia. In Corporate Governance and International Business (pp. 266-279). London: Palgrave Macmillan

Corporate Knights. (2017). 2017 Best 50 results. http://www.corporateknights. com/reports/2017-best-50/2017-best-50-results-14967251/. Accessed 8 June 2017.

CSR Asia. (2016). Sustainability disclosure in ASEAN: the ASEAN extractive sector. CSR ASIA. http://www.csr-asia.com/report/GRI_ExtractiveReport.pdf . Accessed 15 Apr 2018.

Daub, C. H. (2007). Assessing the quality of sustainability reporting: An alternative methodological approach. Journal of Cleaner Production, 15(1), 75-85.

Dawkins, C., \& Ngunjiri, F. W. (2008). Corporate social responsibility reporting in South Africa. Journal of Business Communication, 45(3), 286-307.

Desjardins Caisse. (2016). Working for you: 2016 social and cooperative responsibility report. https://www.desjardins.com/ressources/pdf/d50-rapportsociale-2016-e.pdf?resVer=1493824024000. Accessed 10 June 2017.

Dobele, A. R., Westberg, K., Steel, M., \& Flowers, K. (2014). An examination of corporate social responsibility implementation and stakeholder engagement: a case study in the Australian mining industry. Business Strategy \& The Environment, 23(3), 145-159.

Donaldson, T., \& Preston, L. E. (1995). The stakeholder theory of the corporation: concepts, evidence, and implications. Academy of Management Review, 20(1), 65-91.

Douglas, A., Doris, J., \& Johnson, B. (2004). Corporate social reporting in Irish financial institutions. The TQM Magazine, 16(6), 387-395.

Downing, P. R. (2003). The Ides of March and the Ides of May. TG International Ltd Management Consultants http://www.magma.ca/ tgil/links/ critiqueldesofMarch.pdf. Accessed 12 Feb 2010.

Eisenhardt, K. M. (1989). Building theories from case study research. Academy of Management Review, 14(4), 532-550.

Elkington, J. (1998). Cannibals with forks: The triple bottom line of sustainability. Gabriola Island, BC: New Society Publishers.

Enbridge. (2017). Enbridge 2016 CSR \& sustainability report. http://csr.enbridge. com/ /media/CSR2/pdf/2016_CSR_Report.pdf?la=en. Accessed 10 June 2017.

Epstein, M., Flamholtz, E., \& McDonough, J. J. (1976). Corporate social accounting in the United States of America: state of the art and future prospects. Accounting, Organizations and Society, 1(1), 23-42.

Fernandez-Feijoo, B., Romero, S., \& Ruiz, S. (2014). Effect of stakeholders' pressure on transparency of sustainability reports within the GRI framework. Journal of Business Ethics, 122(1), 53-63.

Freeman, I., \& Hasnaoui, A. (2011). The meaning of corporate social responsibility: The vision of four nations. Journal of Business Ethics, 100(3), 419-443.

Freeman, R. E. (1984). Strategic management: a stakeholder approach. Boston: Pitman.

Freeman, R. E., \& McVea, J. (2001). A stakeholder approach to strategic management. The Blackwell handbook of strategic management (pp. 183-201).

Frost, G., Jones, S., Loftus, J., \& Laan, S. (2005). A survey of sustainability reporting practices of Australian reporting entities. Australian Accounting Review, 15(35), 89-96.

Fuller, M. (2010). A social responsiveness approach to stakeholder management: lessons from the Canadian banking sector. Journal of Leadership, Accountability and Ethics, 8(2), 51-69.

Fuller, M. (2016). One firm, two reports: associations within and disassociations between financial and CSR reporting components among North America's largest financial institutions. Edmonton: Administration Sciences Association of Canada annual meeting.

Garg, M. (2018). The effect of internal control certification regulatory changes on real and accrual-based earnings management. European Accounting Review, 1-28. https://doi.org/10.1080/09638180.2018.1454336.

Gray, R., Owen, D., \& Maunders, K. (1987). Corporate social reporting: accounting and accountability. Englewood Cliffs: Prentice-Hall International.

Gray, T. (2005). Canadian response to the US Sarbanes-Oxley act of 2002: new directions for corporate governance. Ottawa: Parliamentary Information and Research Service, Library of Parliament.

Hahn, R., \& Kühnen, M. (2013). Determinants of sustainability reporting: a review of results, trends, theory, and opportunities in an expanding field of research Journal of Cleaner Production, 59, 5-21. 
Hahn, R., \& Lülfs, R. (2014). Legitimizing negative aspects in GRI-oriented sustainability reporting: a qualitative analysis of corporate disclosure strategies. Journal of Business Ethics, 123(3), 401-420.

Herremans, I., Nazari, J., \& Mahmoudian, F. (2016). Stakeholder relationships, engagement, and sustainability reporting. Journal of Business Ethics, 138(3), 417-435.

Hillman, A. J. (2005). Politicians on the board of directors: do connections affect the bottom line? Journal of Management, 31(3), 464-481.

Hillman, A. J., \& Hitt, M. A. (1999). Corporate political strategy formulation: a model of approach, participation, and strategy decisions. Academy of Management Review, 24(4), 825-842.

Holder-Webb, L., Cohen, J. R., Nath, L., \& Wood, D. (2009). The supply of corporate social responsibility disclosures among US firms. Journal of Business Ethics, 84(4), 497-527.

HSBC. (2016). HSBC Holdings PLC: strategic report 2016. http://www.hsbc.com/-/ media/hsbc-com/investorrelationsassets/hsbc-results/2016/annual-results/ hsbc-holdings-plc/170221-strategic-report-2016.pdf. Accessed 10 June 2017.

Imam, S. (2000). Corporate social performance reporting in Bangladesh. Managerial Auditing Journal, 15(3), 133-142.

International Integrated Reporting Council (IIRC). (2017). Consultation draft of the International Integrated reporting framework. http://integratedreporting.org/ the-iirc-2/. Accessed 15 July 2017.

loannou, I., \& Serafeim, G. (2017). The consequences of mandatory corporate sustainability reporting. Harvard Business School Available at SSRN: https:// ssrn-com.libproxy.stfx.ca/abstract=1799589. Retrieved 14 Apr 2018.

Keim, G. (2001). Managing business political activities in the USA: bridging between theory and practice. Journal of Public Affairs, 1(4), 362-375.

Knopf, J., Kahlenborn, W., Hajduk, T., Weiss, D., Feil, M., Fiedler, R., \& Klein, J. (2011). Corporate social responsibility. National Public Policies in the European Union. In European Commission. Directorate-General for employment, Social affairs and inclusion. Unit C2, Publications Office of the European Union http://ec.europa.eu.libproxy.stfx.ca/social/BlobServlet?docld=6716\&langld=en. Accessed 12 Apr 2018.

Kochan, T. A., \& Rubinstein, S. A. (2000). Toward a stakeholder theory of the firm: the Saturn partnership. Organization Science, 11(4), 367-386.

Kolk, A. (2005). Sustainability reporting. VBA Journal, 21(3), 34-42.

Kolk, A., Van Tulder, R., \& Welters, C. (1999). International codes of conduct and corporate social responsibility: can transnational corporations regulate themselves? Transnational Corporations, 8(1), 143-180.

Kühn, A. L., Stiglbauer, M., \& Heel, J. (2014). Does mandatory CSR reporting lead to higher CSR transparency? The case of France. Corporate Ownership and Control, 11(2), 29-45.

Laasch, O., \& Conway, R. N. (2015). Principles of responsible management. Stamford: Cengage.

Laplume, A. O., Sonpar, K., \& Litz, R. A. (2008). Stakeholder theory: reviewing a theory that moves us. Journal of Management, 34(6), 1152-1189.

Logsdon, J. M., \& Wood, D. J. (2005). Global business citizenship and voluntary codes of ethical conduct. Journal of Business Ethics, 59(1-2), 55-67.

Maniora, J. (2017). Is integrated reporting really the superior mechanism for the integration of ethics into the core business model? An empirical analysis. Journal of Business Ethics, 140(4), 755-786.

Manulife. (2017). 2016 public accountability statement. Manulife Financial Corporation http://www.manulife.com/servlet/servlet.FileDownload?file= 00P5000000kq0QqEAl. Accessed 22 Apr 2018.

Matten, D., \& Moon, J. (2008). "Implicit" and "explicit" CSR: a conceptual framework for a comparative understanding of corporate social responsibility. Academy of Management Review, 33(2), 404-424.

Mendelow, A. (1981). The stakeholder approach to organizational effectiveness. Pretoria: School of Business Leadership, University of South Africa.

Miles, M. B., \& Huberman, A. M. (1994). Qualitative data analysis. London: Sage.

Miles, M. B., Huberman, A. M., \& Saldana, J. (2014). Qualitative data analysis: a methods sourcebook. Thousand Oaks: Sage.

Naser, K. (1999). Empirical evidence on corporate social responsibility reporting and accountability in developing countries: the case of Jordan. Advances in International Accounting, 12, 193-226.

Naser, K., Al-Hussaini, A., Al-Kwari, D., \& Nuseibeh, R. (2006). Determinants of corporate social disclosure in developing countries: the case of Qatar. Advances in International Accounting, 19, 1-23.

O'Rourke, D. (2004). Opportunities and obstacles for corporate social responsibility reporting in developing countries. The World Bank Group œe Corporate Social Responsibility Practice Mar, 27, 39-40.
Orzes, G., Moretto, A. M., Ebrahimpour, M., Sartor, M., Moro, M., \& Rossi, M. (2018). United Nations global compact: literature review and theory-based research agenda. Journal of Cleaner Production, 177, 633-654.

Patton, M. Q. (2002). Qualitative research and evaluation methods. Thousand Oaks: Sage.

Perrini, F. (2005). Building a European portrait of corporate social responsibility reporting. European Management Journal, 23(6), 611-627.

Pfeffer, J., \& Salancik, G. R. (1978). The external control of organizations: a resource dependence approach. New York: Harper and Row Publishers.

Pled, V., \& Latridis, G. E. (2012). Corporate social responsibility reporting: Evidence from environmentally sensitive industries in the USA. International Review of Accounting, Banking \& Finance, 4(2), 61-99.

Post, J. E. (1978). Corporate behavior and social change. Reston: Reston Pub. Co..

Reynolds, M., \& Yuthas, K. (2008). Moral discourse and corporate social responsibility reporting. Journal of Business Ethics, 78(1), 47-64.

Roca, L. C., \& Searcy, C. (2012). An analysis of indicators disclosed in corporate sustainability reports. Journal of Cleaner Production, 20(1), 103-118.

Sethi, P. (1971). Up against the corporate wall. Englewood Cliffs: Prentice Hall.

Sierra-García, L., Zorio-Grima, A., \& García-Benau, M. A. (2015). Stakeholder engagement, corporate social responsibility and integrated reporting: an exploratory study. Corporate Social Responsibility \& Environmental Management, 22(5), 286-304.

Spreckley, F. (1981). Social audit-a management tool for co-operative working. Leeds: Beechwood College.

Sunlife. (2016). 2016 sustainability report. Sunlife financial https://cdn.sunlife.com/ static/Global/In\%20the\%20community/Sustainability/SLF_ Sustainability\%20Report_EN_2016.pdf. Accessed 10 June 2017.

Thompson, P., \& Zakaria, Z. (2004). Corporate social responsibility reporting in Malaysia. Journal of Corporate Citizenship, 13, 125-136.

Tuczek, F., Castka, P., \& Wakolbinger, T. (2018). A review of management theories in the context of quality, environmental and social responsibility voluntary standards. Journal of Cleaner Production, 176, 399-416.

UNPRME. (2017). History: United Nations principles for responsible management education. United Nations. http://www.unprme.org/about-prme/history/ index.php. Accessed 16 July 2017.

Van den Bergh, R. (1976). The corporate social report-the Deutsche Shell experience. Accountancy, 88, 57-61.

Vancity. (2017). Vancity in 2016: Building on our values. Vancity. https://www. vancity.com/SharedContent/documents/AnnualReportArchives/Nancity_ AR2016.pdf. Retrieved 23 Apr 2018.

Vazquez-Brust, D., Liston-Heyes, C., Plaza-Úbeda, J., \& Burgos-Jiménez, J. (2010). Stakeholders pressures and strategic prioritisation: an empirical analysis of environmental responses in Argentinean firms. Journal of Business Ethics, 91, 171-192.

Vogel, D. (2008). Private global business regulation. Annual Review of Political Science, 11, 261-282.

Waddock, S. (2004). Parallel universes: companies, academics, and the progress of corporate citizenship. Business \& Society Review (00453609), 109(1), 5-42.

Wang, Q., Dou, J., \& Jia, S. (2016). A meta-analytic review of corporate social responsibility and corporate financial performance. Business \& Society, 55(8), 1083-1121.

Wheeler, D., \& Sillanpää, M. (1997). The stakeholder corporation: a blueprint for maximizing stakeholder value. Boston: Pitman.

Wood, D. J. (1991a). Corporate social performance revisited. Academy of Management Review, 16(4), 691-718.

Wood, D. J. (1991b). Social issues in management: Theory and research in corporate social performance. Journal of Management, 17(2), 383-406.

Wood, D. J., \& Jones, R. E. (1995). Stakeholder mismatching: a theoretical problem in empirical research on corporate social performance. International Journal of Organizational Analysis (1993 - 2002), 3(3), 229.

Wu, W. P., \& Choi, W. L. (2004). Transaction cost, social capital and firms' synergy creation in Chinese business networks: an integrative approach. Asia Pacific Journal of Management, 21(3), 325-343. 